\title{
The Digital Library of the Middle East and Implementing International Cultural Heritage Preservation Policy
}

\author{
Peter Herdrich ${ }^{1,2}$ \\ 1 The Antiquities Coalition, US \\ 2 Digital Library of the Middle East, US \\ peterherdrich@gmail.com
}

This article reviews the origins and goals of the Digital Library of the Middle East and discusses how the DLME and other digital library projects implement international cultural heritage preservation policy.

Keywords: Digital Library; Looting; Trafficking; Preservation; Policy; United Nations; 2347

In a February 2015 spasm of libricide, the terrorists of Daesh attacked the central library in Mosul, Iraq, reportedly destroying up to 100,000 books, early twentieth-century newspapers, maps, and collections from the Ottoman period. UNESCO director general Irina Bokova called it cultural cleansing and 'one of the most devastating acts of destruction of library collections in human history' (Fadhil 2015). That same week, the infamous Daesh videotape of the desecration of the Mosul Museum appeared. Seeing sledgehammers and electric drills taken to statuary and to the famous lamassu from the Nergal Gate reinforced the selfproclaimed caliphate's extremist violence, sickening observers around the world who care about our shared cultural heritage.

With the horrifying loss of life and human toll extracted by the terrorists, this episode was a galvanizing, urgent moment. We learned that the world's shared heritage was at risk, even in libraries and museums. Data and knowledge were existentially endangered.

Volunteers organized by the Council on Library and Information Resources (CLIR) and the Antiquities Coalition authored a reply. It was the Digital Library of the Middle East (DLME), a large-scale, open-source digital platform focused on Middle Eastern culture with three principal goals: creating global accessibility to the revelatory fluorescence of Middle Eastern culture; doing all we could to preserve and protect collections, especially in areas at risk; and promoting global partnerships with communities across the Middle East and North Africa.

The urgency of cultural heritage loss required that we come a long way quickly. With the generous support of a study grant from the Andrew W. Mellon Foundation in 2016, we built a team and surveyed interested parties around the world, asking if they thought a globally accessible, interoperable platform federating collections about the cultural heritage of the Middle East was an important goal. Almost uniformly, libraries, archives, special collections, museums, archaeological and intangible heritage collections, and individuals said yes and offered assistance.

A community took shape around the DLME. Foundational partners at the Stanford Libraries and the Qatar National Library joined the effort. The Antiquities Coalition and CLIR provided resources and leadership, particularly from the dedicated staff at CLIR, where the DLME is incubating, and from the Digital Library Federation. A grant from the Whiting Foundation allowed us to create a prototype for the digital platform and online exhibits, taking us from vaporware to reality. And in April 2018, the Mellon Foundation granted us the funds to continue technical development of the digital platform, a significant step in expanding functionality and sustainability. Next steps for the Digital Library of the Middle East include significantly 
expanding engagement and collaboration with collections, institutions, experts, and communities in the MENA region (including funding digitization projects and capacity building), increasing federation with regional collection holders, and focusing on collections at risk in conflict areas.

These steps in the formation of the Digital Library of the Middle East speak to our engagement with endangered data and collections. They also address a critical goal in international cultural heritage policy. In 2017, the United Nations unanimously passed Security Council Resolution 2347. This resolution suggests preventative steps that each UN Member State can take to strengthen its system of cultural heritage protections. The first recommendation codified in Section (a) of Article 17 of UNSC Resolution 2347, concerns key library issues. It

17. Calls upon Member States, in order to prevent and counter trafficking of cultural property illegally appropriated and exported in the context of armed conflicts, notably by terrorist groups, to consider adopting the following measures, in relation to such cultural property: (a) Introducing or improving cultural heritage's and properties' local and national inventory lists, including through digitalized information when possible, and making them easily accessible to relevant authorities and agencies, as appropriate.

Digital libraries around the world are actively implementing inventory, digitization, and accessibility projects at a prodigious rate. In many instances, these projects are models of multilateral international cooperation and are occurring in a vast group of UN Member States. Digital libraries like the Digital Library of the Caribbean, the DLME, the Endangered Archives Program at the British Library, Europeana, and the International Digital Ephemera Project at UCLA are just some examples of organizations that are implementing these goals at scale. We would suggest that digital libraries represent one of the areas in which unified cultural heritage preservation policy is most actively taking hold.

Is your library or collection implementing these stated United Nations goals? If the answer is yes, then you are participating in the worldwide effort to combat the cultural racketeers, pushing back against the forces that would destroy and traffic irreplaceable treasures like those from the library and museum in Mosul.

\title{
Competing Interests
}

The author has no competing interests to declare.

\section{References}

Fadhil, Muna. 2015. "Isis destroys thousand of books and manuscripts in Mosul libraries." The Guardian, February 26, 2015. https://www.theguardian.com/books/2015/feb/26/isis-destroys-thousands-bookslibraries.

UN Security Council, Resolution 2347, Maintenance of international peace and security, S/RES/2347, II 36 (March 24, 2017). https://undocs.org/S/RES/2347(2017).

\begin{abstract}
How to cite this article: Herdrich, Peter. 2018. The Digital Library of the Middle East and Implementing International Cultural Heritage Preservation Policy. KULA: Knowledge creation, dissemination, and preservation studies 2(1): 18. DOI: https://doi.org/10.5334/kula.38
\end{abstract}

Submitted: 10 May 2018 Accepted: 11 July 2018 Published: 29 November 2018

Copyright: (c) 2018 The Author(s). This is an open-access article distributed under the terms of the Creative Commons Attribution 4.0 International License (CC-BY 4.0), which permits unrestricted use, distribution, and reproduction in any medium, provided the original author and source are credited. See http://creativecommons.org/ licenses/by/4.0\%

$\mathrm{u} \mid$

KULA: knowledge creation, dissemination, and preservation studies is a peer-reviewed open access journal published by Ubiquity Press 